\title{
THE INVESTIGATION OF VOLUNTARY SIMPLICITY LIFESTYLE FROM THE POINT OF PERSONALITY CHARACTERISTICS: A RESEARCH ON CLOTHING (GARMENTS AND SHOES) PRODUCT GROUP
}

\author{
Metin SAYGILI \\ Sakarya University / TURKEY, Phd. Student, E-mail: mtnsaygili@gmail.com \\ Erkan BILL \\ Çanakkale Onsekiz Mart University / TURKEY, E-mail: erkanbil@ comu.edu.tr
}

\begin{abstract}
Today's market conditions made it hard for the enterprises to find new customers or to retain the existing customers due to the fact that the differences between products and services diminished. In relation to determination by the enterprises the customer preferences towards products and services they provide under these conditions, it has become important to know the lifestyles and personality characteristics of them. For that reason, the differentiation of value imposed on shopping, a search for simplicity in products and services and in particular changing shopping and life styles with the dissemination of shopping behaviors that became environmentally sensitive made it important to examine the behaviors of individuals both towards shopping in terms of their personality characteristics and also towards their life and purchasing styles. In this regard, it has become necessary to study the shopping frequencies and shopping times of consumers for clothing (garments and shoes) product groups, which product groups they purchase in their shopping and what is the rank of shopping for clothing (garments and shoes) product groups among the product groups that are purchased, and how they evaluate the elements towards shopping for clothing (garment and shoes) product groups. Based on this notion, the basic purpose of this study is to examine the voluntary simple life styles of consumers from the point of their personality characteristics. In this regard, the aim was to determine whether the voluntary simplicity lifestyle differentiates depending on the personality characteristics (type $A-B$ ). The sample of this research, in which positivist research approach was adopted, comprises consumers aged 18 and above who do clothing (garments and shoes) shopping from a shopping mall in Sakarya province. The data of the research was obtained through easy sampling method and face to face surveys with 190 students who accepted to participate
\end{abstract}




\section{$\int\left(\begin{array}{c}\text { Journal of Life } \\ \text { Economics }\end{array}\right.$}

in the study as volunteers. The research data was teste with SPSS 21.0 statistical analysis software and the exploratory factor analysis, independent samples $t$ test and definitive statistics were used in the research.

The results of the research demonstrate that among the dimensions which constitute voluntary simplicity life style, the responses given in relation to type $A$ and B personality characteristics in three of the sub-dimensions other than self-sufficiency dimension, had statistically significant difference. Results of the study demonstrate that the averages of responses given in the three dimensions (planned behavior, simplicity in product and intangible life) show that participants having type B personality are directed more towards more planned shopping and also they looked from simplicity in the product and also they adopted an intangible life style, compared to participants having type A personality in statistical terms.

Keywords: Voluntary Simplicity Lifestyle, Personality Traits, Type-A and Type-B Personality

JEL Codes: M30, M31

\section{INTRODUCTION}

In today's develop societies where the individual consumption increased at a considerable pace, the negative impacts on the society and environment of consumption behaviors that are owned and supported by the media, lead to the questioning of the meaning and content of consumption. In particular the consumption culture which rapidly spread overall the world with the effect of globalization, turned the consumption from being a means for realizing the ends, into the ends itself, making the individualization and self-expression through consumption in a society the main objective of life. In this regard, a society structure which aims at reaching happiness through consumtion, which is one of the main assumptions of hedonism, has emerged. However, researches conducted demonstrate that the impact of over-consumption on happiness is limited (Myer,2003). Therefore, there is a need to requestion the meaning of happiness in the process of passing from industrial society to the consumption society. The voluntary simplicity could be characterized as a stream that has emerged in this context. In the literature the term "Voluntary Simplicity Lifestyle" is also expressed as "Voluntary Simplicity".

One of the issues that are frequently studies in the marketing literature is the shopping behaviors of consumers towards products and services, purchasing and life styles. It could be seen in the consumer behavior literature that there is no sufficient research which associates the life styles, in particular the voluntary simplicity lifestyle, with the approach related to type A and type B personality characteristics. For that reason, there was a motive in this study for filling out this gap and also studying the voluntary simplicity life styles of consumers in relation to their personality characteristics.

Marketing, which aims at determining the needs and desires of the customers and satisfying these in the most appropriate manner, examines the personality characteristics of the consumers, as well as their purchasing behaviors and the process before and after this behavior, as well as factors that affect these behaviors (Kutlu,2016:7). For that reason, the personality and life style, which are among the important factors that affect the consumer behaviors, constitute the subject of this study. 


\section{CONCEPTUAL FRAMEWORK}

This section handles the concepts of voluntary simplicity lifestyle and personality characteristics. Information on the concepts if given in the following section.

\subsection{Voluntary Simplicity Lifestyle}

Gregg (1936), who first defined the concept of voluntary simplicity lifestyle, emphasized the spiritual dimension of voluntary simple lifestyle. As the definitions developed by researchers and authors diversified and turned into different dimensions in the following years, it would not be an error to say that, when taken as a life style and philosophy, the phenomenon of consumption is at the center of voluntary simplicity although it mightnot be considered as having direct connection with consumption at first sight. Elgin and Mitchell (1977) suggested that the voluntary simplicity is a lifestyle which is visibly simple but which is prosperous or rich in spiritual terms. When seen from this perspective, it is possible to define voluntary simplicity as an experience which every individual could discover himself in his own life conditions. (Elgin,2010:67). Together with this, a life style which is seemingly simple but rich in spiritual terms, encompasses in it the austerity in consumption, a strong environmental sensitivity, desire for more humane living and working conditions and attaining a higher level of psychological and spiritual potential in the community. Nelson, Rademacher and Paek (2007) suggest that minimizing the consumption and voluntary simplicity are synonims and emphasize that getting rid of material belongings is a style of life. In addition to this, the authors also expressed that refraining from excessiveness and extremisms in the life of an individual is also equal to a voluntary simplicity lifestyle (Gregg, 1936; Elgin, 1981; Zavestoski, 2002; Iyer ve Muncy, 2009). In another definition, it is stated that voluntary simplicity puts the emphasis on seeking the satisfaction in non-commercial and intangible aspects of life and limiting the material consumption. (Huneke,2005). In this regard, the concept of voluntary simplicity questions the definition of "good living" of modern society, and defends for a less materialistic life style which enriches the inner world of an individual, is beneficial in social terms and sustainable in environmental terms. (Johnson, 2004). Therefore, it could be stated that at the core of voluntary simplicity lies a life which is as simple as it could be in the external life of an individual, and is also rich and deep in its inner world (Odabaşı,2006; Elgin,1993).

There are some cases where the Voluntary Simplicity Lifestyle is offered as a solution of social and individual problems caused by materialistic consumption (Friedman and Friedman,2010). Voluntary Simplicity is a philosophy of life which promises for the attainment of spiritual richness as a result of strengthening and improving relations with the environment instead of focusing on material richness. In this regard, the environment mentioned includes both the natural environment and the social environment. In this regard, living in rural areas rather than developed urban centers, consuming environmentally friendly products, using bicycle rather than automobile, emphasizing the recycling of the products and consuming the natural resources in a conscious manner in line with the needs rather than desires refer to relationships with the natural environment. Spending more time with family and friends, participating in community and social projects, spending more time outside the work refer to social environment (Cengiz,2014:24).

\subsubsection{Demographic and Behavioral Characteristics of Consumers Who Adopt Voluntary Simplicity Lifestyle}

It is possible to express that persons who preferred a voluntary simplicity lifestyle apparently have common demographical characteristics. Studies conducted demonstrate that 


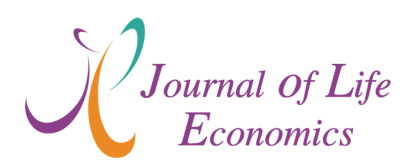

individuals who prefer voluntary simplicity lifestyle generally comprise families with higher level of education and no children (Craig-Lees ve Hill,2002:193). Pierce (2000) confirmed that the level of education of individuals who adopt voluntary simplicity life is high. Brown and Kasser (2005) found in their researches that $77 \%$ of the subjects hold at least two-year degree and half of these hold masters degree. Elgin and Mitchell (1977), Nolen and Clawson (1995) and Schor (1998) underlined that more than $60 \%$ of individuals who live voluntary simplicity life were females, with a general age level of around 40. Results of researches conducted on individuals who preferred voluntary simple life differ according to the cultures. Elgin and Mitchell (1977) expressed in the researches they carry out in the US that individuals who preferred voluntary simplicity life predominantly comprised white Americans.

Academicians who study on voluntary simplicity do not accept that there is one single common method which defines the characteristics of those who have voluntary simplicity lives (Cowles and Crosby,1986:393). Together with this, the most important activities carried out by those who have voluntary simplicity living are, in the same order, refraining from purchasing behavior, recycling products which they use, refraining from the complexity of life, working in jobs which make them happy and to consume products which are locally produced (Huneke, 2005:538).

Elgin and Mitchell (1977) indicate that individuals who prefer voluntary simplicity life use solar energy system and that they produce their own breads. In addition to these, wearing simple clothes rather than luxurious clothes and purchasing these clothes from shops or persons which sell second hand clothes are preferred widely by individuals who prefer voluntary simplicity life.

Leonard-Barton (1981) concluded that among the leading characteristics of individuals who prefer voluntary simplicity life are performing lubrication replacement of their vehicles by themselves, making the gifts themselves rather than purchasing them, eating the food without meat and attending the courses in order to increase their self-esteem. In addition to this, those who live voluntarily simple take precautions against cold by insulating their doors and windows in order to save energy instead of increasing the heater level.

Individuals who prefer voluntary simplicity life prefer vehicles which are less attractive, consume less energy and damage the environment less, and adopt the way of living in harmony with the environment and using resources efficiently (Doherty and Etzioni,2003:22; Elgin, 2010:110).

Etzioni (1988) stated that individuals who prefer voluntary simplicity life spend their times by living amidst the nature and cooperating with companies which are sensitive for the environment. In addition to this, individuals who preferred a voluntary simplicity life are those who stay away from stressful environment, work less, demand for retirement at early age and who have taken radical decisions such as reconstructing their lives.

For individuals with voluntary simplicity life, quality is an indispensable element. Many people who have voluntary simplicity life keep the quality foremost in their purchasing behaviors. At the basis of this is the assumption that products of higher quality will be stronger (Ballantine and Creery,2010:52). Therefore, it could be said that who have simple lives would preferred quality products despite them being expensive.

Elgin (2010) defines individuals with voluntary simplicity life as people who are more sensitive for social issues such as social justice overall the world and just use of resources and those are selective and contented in their consumption alternatives. In addition to these, the 


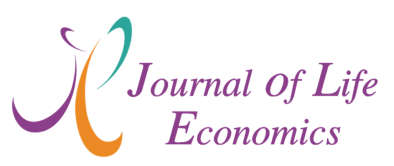

product they purchase generally comprise endurable products which are easily repair, are functional, environmentally friendly and aesthetical. They reduce complexity in their lives by giving or selling the products they do not use or use occasionally to those who could use them in a more efficient manner. They have the character of politically orienting their consumption behaviors when required. They could engage in the effort to boycott and thus direct the products and services of an enterprise which they do not considered to act in an ethical manner.

\subsubsection{Evaluation of Academic Studies Conducted on Voluntary Simplicity}

When we look at the studies conducted on voluntary simplicity in Turkey, we see that the number of studies in relation to the subject is quite limited. When these studies are examined:

- In its work, Özgül (2009) studies the voluntary simplicity lifestyle together with sustainable consumption. In another work, Özgül (2011) studies the relationship between hedonic consumption and voluntary simplicity lifestyle.

- Babaoğul and Buğday (2012) studies voluntary simplicity in relation to luxurious consumption. Argan, Argan and Sevim (2012), studied the impact of attidues related to voluntary simplicity on the voluntary voluntary simplicity lifestyle

- Although not directly related to voluntary simple life, Aslay, Ünal and Akbulut (2013) made a research on the impact of materialism on consumption where they suggest that there is a relationship between materialism and simple life.

When the international literature is evaluated, the basics of the issue are constructed by the study of Elgin and Mitchell (1977). After Elgin and Mitchell (1977) studied voluntary simplicity in their works in conceptual framework, the interest on literature has become more emphasized both for academicians and implementers. In this regard, they demonstrated five fundamental values related to voluntary simplicity and four stages of voluntary simplicity life levels.

- Leonard-Barton (1981) who carried out research about the characteristics of voluntary simplicity lifestyle, developed a scale of 18 expressions towards measuring voluntary simplicity and energy saving. Findings which are obtained from the scale applied to consumers who live in California state of the United States of America, gave clues in relation to characteristics of life style in question.

- Dominguez and Robin (1992) discussed what are the financial changes that are required for having a simple life style.

- In their studies where they demonstrate the characteristics of voluntary simplicity life, Craig-Less and Hill (2002) carried out a qualitative research on two different consumer groups who preferred and did not prefer voluntary simplicity life.

- Bekin, Carrigan and Szmigin (2005) analyzed what were the experiences of individuals who prefered this life style in order to better understand the voluntary simplicity life.

- $\quad$ Etzioni (1998), Zavestoski (2002) and Huneke (2005) used Maslow's (1954) Theory of Hierarchy of Needs in order to explain the voluntary simplicity. Accordingly, individuals whose basic needs are continuously covered have the option to have a simpler life. A high portion of studies included in the literature comprise the works that are directed towards explaining who are those who prefer voluntary simplicity life, why they prefer a voluntary simplicity life and how they sustain such life style (Walther and Sandlin, 2013). 


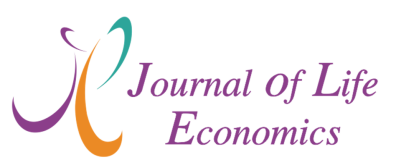

Based on the studies in the literature (Elgin and Mitchell,1977; Ensley,1983; Etzioni,1998; Huneke,2005; Zavestoski,2002; Shama,1981,1988,1985; Leonard-Barton,1981; Craig-Lees and Hill,2002) it is possible to express that the sub-values of voluntary simplicity are conscious consumption, self esteem, free will, self-expression, self-sufficiency, selfrespect and self- realization. When considered from this aspect, the objective is to adopt a "simpler life style" as recommended by these concepts in a holistic manner.

Elgin and Mitchell (1977) indicated that voluntary simplicity has 5 fundamental values: These are material simplicity, humanistic scale, free will, environmental sensitivity, personal development (ref.Cengiz,2014:29). Shama (1985) suggests that voluntary simplicity lifestyle comprises six fundamental dimensions. These are material simplicity, determinism, environmental sensitivity, humanistic scale, personal development and technology. In relation to the issue, Cowles and Crosby (1986) re-interpreted the work by Leonard-Barton (1981) and suggested a simpler grouping and defended that the dimensions of material simplicity, person being a determinant in his/her life and ecologic awareness dimensions are effective in measuring the level of voluntary simplicity (ref.Özgül, 2011). Iwata on the other hand studied voluntary simplicity as life style and demonstrated this in the scale development studies he has conducted and he suggested in that research that the voluntary simplicity lifestyle could be studied under three dimensions, being a prudent attitude towards shopping, self-sufficiency in terms of income and expenditure and a desire to have a simple life style.

\subsection{Personality and Basic Characteristics}

As one of the psychological factors that affect consumer behaviors, personality is important since it is important to understand human behavior in order to understand consumer behavior. (Odabaşı ve Barış,2006:36). When we consider the subject of personality from the point of view of consumer behaviors, it could be seen that it is one of the important variables in determining the shopping preference. Taken from this aspect, personality in general terms covers the most typical behaviors of an individual which distinguishes him/ her from other individuals and which are done with frequency.

Personality could be expressed as a whole of characteristics that are specific to an individual. Personality of an individual affects his/her the work life, social life, social environment and habits. Even it would not be wrong to say that personality structures affect the whole life of human beings (Tutar,2015).

Personality and characteristics of an individual are the basic characteristic that distinguish that person from other individuals and cover the whole psychological characteristics of an individual (Altunışık et al.2006:69) Personality, which covers the emotions, motives, desires, habits and all behavioral characteristics of individuals, has an impact on purchasing behaviors of individuals (Demirel,2013:67).

Another issue where the personality is studied from the point of consumer behaviors is related to the approaches of consumers towards consumption. According to their approaches towards consumption, consumers could be divided into such groups as those who lead acceptance of innovations, those who are understanding and easy to get along with, those who are open for collaboration and those who are unwilling for sales though being collaborative, and those who do not want to take risk. Trying to understand these groups and the characteristics of these groups will have great benefits on the marketing implementers. (Altunışık et al, 2006: 70). 


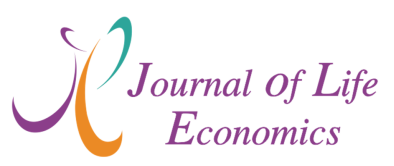

Based on the definitions of personality provided above, the fundemental characterisics of the concept of personality can be listed as follows: (Eren,2000; Zel,2011; Erdoğan,1994; Somer et al.,2004; Cüceloğlu,2003: ref. Kutlu,2016:13);

- Personality comprises the whole of tendencies which come from birth and are acquired thereafter.

- Personality is the regulation of these acquired tendencies and as a result of this, it is possible to speak about a structure created by these tendencies.

- There are characteristics which differentiate an individual from the other and numerous different personalities are created as a result of these differences.

- Based on the definitions of personality which have similarities on such points as personality being a consistent and long-term tendencies and being created by internal reasons related to the individual, it could be concluded that personal characteristics give clues in relation to social behaviors of individuals.

- Every individual has a characteristic acquired from birth and this character is an indispensable element from the point of personality of an individual.

- A person's personality has an impact on the form of relationship it establishes with his interior and exterior environment. Personality which is defined as the "form of relationship" is no more an abstract theory, rather it becomes a concrete concept that could be observed in the everyday behaviors of the individual.

- The personality is a product of individual balance. Personality occurs as a result of normal mental balance of an individual and the more mental balance an individual has, the more normal behaviors the personality will demonstrate and the individual will have a normal personality.

- Personality is the whole of behaviors within a specific time slice the personality occurs as a result of past, today and the future time. An individual acquires certain characteristics with his/ her past experiences, makes certain regulations in his/ her behaviors during lifetime and creates plans for himself / herself for the future.

- Personality makes the tendencies of individuals in harmony with the environment. Therefore, same individual could demonstrate different behaviors and attitudes under different environmental conditions (social cohesion).

All of these characteristics mentioned above constitute a concept that is a whole in itself. In addition to these characteristics which personality bears, several factors such as genetic and physical structure factors, socio-cultural factors, family factor, social class factor, geographical and physical factors have an impact on the formation of personality (Kutlu,2016:13)

\subsubsection{Type A and B Personality Characteristics}

Since personality defines the unique characteristics of human beings, it could be said that every human being has a unique personality of his/ her own. In a definition made by Tutar (2015), personality is created by such elements as mood, character and capabilities, and that it could be spoken of personalities equal to the number of human beings. As it could be understood from this definition, it is not possible to identify the personality characters in an exact manner. For that reason, for determining the personality structures of individuals, researchers draw a framework with general expressions by adopting personality structures to certain patterns under the title of personality types. There are several personality inventories in relation to this field of which validity and reliability have been ensured and numerous studies have been conducted in relation to the issue. When we look at the studies conducted in relation to the issue, it is possible to define the personality type as a system which ensures 
understanding what the individuals do for which reason, as well as understanding the natural tendencies of individuals in their unique preferences (Balkis,2003). When the relevant literature is examined, it could be seen that the personality characteristics have been studies by researchers by means of different scales. This study deals with personality characteristics as type A and type B personality structures. Type A and Type B personality structures are observed by the cardiologists Meyer Friedman and Rosenman. Friedman and Rosenman stated that people could not be purely type A or type B character, that they could have more tendency towards one of these two personality types (Durna,2005).

Individuals who demonstrate the characteristics of type A personality love competition, working and they devote themselves to their jobs. They are sensitive against time and they have a hasty character. Individuals who have type A personality generally walk fast, talk fast, and try to make several works at a time. Persons of such character could fall into stress very quickly and they could be stressful even under normal conditions (Lelord and Andre,1996). Individuals with type A personality characteristics are continuously in a rush and they always tend to do something. These kind of people generally fail in time management (Aytac,2002).

Individuals demonstrating type B personality characteristics are not that much competitive and as opposed to individuals demonstrating type A personality characteristics, they are the ones who devote themselves less to their work and they are not in a rush with time. Individuals demonstrating type B personality characteristics have a more balanced and relax approach towards their work and social lives. Individuals with type B personality characteristic feel themselves safer. They are not perfectionists, they are not excessively ambitious, as opposed to those who demonstrate type A personality, they have a rather malleable and hard to get angry type of character. (Durna, 2005). Besides, people demonstrating this type of personality have a less exciting character and they do not engage in haste, are calm, not in rush, and use time a more comfortable way (Yurtsever, 2009: 65). Individuals demonstrating type B characteristic know how to enjoy the work they do, they work regularly and calmly (Guney, 2000: 446).

Table 1. Type A and B Personality Characteristics

\begin{tabular}{|l|l|}
\hline \multicolumn{1}{|c|}{ Type A Personality Characteristic } & \multicolumn{1}{c|}{ Type B Personality Characteristic } \\
\hline They are always in an action & They have no sense of time \\
\hline They walk fast. & They are patient \\
\hline They eat fast & They do not like to be praised \\
\cline { 1 - 2 } They talk fast & $\begin{array}{l}\text { They perform games and sports not to win, } \\
\text { but to enjoy }\end{array}$ \\
\cline { 1 - 2 } They are impatient & They rest with an inner serenity \\
\cline { 1 - 2 } They do two things at a time & $\begin{array}{l}\text { They are not under the pressure of finishing } \\
\text { the work immediately . }\end{array}$ \\
\cline { 1 - 1 } They have not leisure time & They are accommodating \\
\cline { 1 - 1 } They are obsessed against numbers & They rest with an inner serenity \\
\cline { 1 - 1 } They tend to measure success in numvers & They are never in haste \\
\cline { 1 - 1 } They are aggressive & \multicolumn{2}{|l}{ They are competitive } & \\
\cline { 1 - 2 } They are always under the pressure of time &
\end{tabular}

Source: Luthans, 1995; ref.Durna, 2005. 


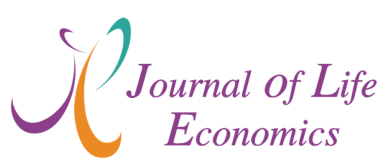

When the literature is studied, it could be seen that there are researches conducted on the behaviors and tendencies of individuals who demonstrate type A and type B personality characteristics. This study has identified its subject of research whether the voluntary simple life style demonstrates any difference among personality characteristics.

When the marketing literature is examined, it could be seen that the issue of personality within the context of marketing has been the subject of many studies since past. When studied from this aspect, it is possible to express that there are numerous researches that have been dealing with the relationship between personality and personality characteristics and various marketing variables. When considered from this aspect, it could be possible to reach conclusions about marketing and consumers by establishing relations between the brands and products/ services through studies to be conducted on personality characteristics and life styles by the academicians who are studying on marketing science, and implementers in the field of marketing and the marketing workers. Meanwhile, taking into account the life style studies that could be carried out, it could be possible to determine the market positions of products in relation to which life styles adopted by the customers could be associated with which personality characteristics as we study collectively the works on life styles of the consumers and their personality characteristics.

\section{METHOD}

\subsection{Purpose of the Research}

The basic objective of the study is to examine the voluntary simplicity lifestyles of consumers from the point of their personality characteristics. In this regard, the aim was to determine whether the voluntary simplicity lifestyle differentiates depending on the personality characteristics (type A - B).

The questions for which answers are sought in this study could be listed as follows:

1. How are the shopping frequencies and shopping times of participants towards clothing (garments and shoes) product groups?

2. Which product group do the participants purchase in their shopping and what is the rank of clothing (garments and shoes) among the product groups that are purchased during this shopping?

3. How are the elements that have impact on the shopping by participants of clothing (garments and hoes) product groups evaluated?

4. What are the factors that make of voluntary simplicity lifestyle and how do these go along with the literature?

It is considered that the responds to be given to these questions will be beneficial for both the researchers and the academicians working in this field.

\subsection{Sample of the Research and Data Collection}

The sample of this research comprises consumers aged 18 and above who do clothing (garments and shoes) shopping from a shopping mall in Sakarya province. The data of the research was obtained through easy sampling method and face to face surveys with 190 students who accepted to participate in the study as volunteers. It was assumed that the sample of the research was large enough for statistical analysis, that the expressions in the 


\section{$\int\left(\begin{array}{c}\text { Journal of Life } \\ \text { Economics }\end{array}\right.$}

scales are correctly understood and the participants in the research responded in a true manner.

The findings of the research are confined to the sample and expressions in the questionnaire, and any comment asserted in the research is limited to the participants of the research, the data collection means and those who could be reached among students who are being educated in the university in question.

\section{DATA ANALYSIS AND FINDINGS}

This section includes findings related to data which is subjected to statistical analysis within the scope of the research.

\subsection{Demographical Characteristics of Participants}

Characteristics for 190 participants who are included in the research are presented in Table 2 and the demographical characteristics of participants have been evaluated.

Table 2. Demographical Characteristics of Participants

\begin{tabular}{|c|c|c|c|}
\hline Specifications & Options & f. & $\%$ \\
\hline \multirow{2}{*}{ Sex } & Woman & 105 & 55,3 \\
\hline & Man & 85 & 44,7 \\
\hline \multirow{5}{*}{ Educational Status: } & $\begin{array}{l}\text { Elementary } \\
\text { Education }\end{array}$ & - & - \\
\hline & High School & 24 & 12,6 \\
\hline & Associate degree & 10 & 5,3 \\
\hline & License & 141 & 74,2 \\
\hline & Masters & 15 & 7,9 \\
\hline \multirow{4}{*}{ Age } & $18-20$ & 38 & 20 \\
\hline & $21-23$ & 110 & 57,9 \\
\hline & $24-27$ & 29 & 15,3 \\
\hline & 28 and above & 13 & 6,8 \\
\hline \multirow{6}{*}{$\begin{array}{l}\text { Monthly Average } \\
\text { Personal Income }\end{array}$} & Less than $1000 \mathrm{TL}$ & 132 & 69,5 \\
\hline & $1001-1250 \mathrm{TL}$ & 21 & 11,1 \\
\hline & $1251-1500 \mathrm{TL}$ & 18 & 9,5 \\
\hline & $1501-1750 \mathrm{TL}$ & 5 & 2,6 \\
\hline & $1751-2000 \mathrm{TL}$ & 3 & 1,6 \\
\hline & $2501 \mathrm{TL}$ and above & 11 & 5,8 \\
\hline
\end{tabular}

When we evaluate the demographic characteristics of participants, it could be seen that $55.3 \%$ of the participants are male students and $44.7 \%$ are female students. When the participants are analyzed for their ages, it could be seen that the educational level of a high portion of students who participated in the research was $(\% 72,4)$, and the rate of students with high school education level was $12.6 \%$. When the ages of the participants is evaluated, it could be seen that more than half of the participants are aged between 20 and $23(\% 57,9)$ and students aged between 18-20 constitute $20 \%$ of the research. When the monthly personal incomes of students who participated in the research are evaluated, it could be seen that around $70 \%$ of them had an income that is less than 1000 TL. 


\section{$\int$ Journal of Life \\ Economics}

\section{Product Group}

\subsection{General Information On Shopping For Clothing (Garments and Shoes)}

In the research, the participants were asked the purchasing frequencies for clothing (garment and shoes) product group, as well as when was the last time they shopped. Table 3 shows the frequency distribution of responds given.

\section{Table 3. Participants' Frequency and Times of Purchasing Clothes (Garments and Shoes)}

\begin{tabular}{|c|c|c|}
\hline Purchasing Frequency & Frequency & \% \\
\hline Once a week & 8 & 4,2 \\
\hline A couple of times a month & 94 & 49,5 \\
\hline Once a month & 49 & 25,8 \\
\hline A couple of times a year & 36 & 18,9 \\
\hline Less frequent & 3 & 1,6 \\
\hline $\begin{array}{c}\text { The Last Time They } \\
\text { Shopped }\end{array}$ & Frequency & \% \\
\hline Within the last week & 55 & 28,9 \\
\hline Within the last month & 94 & 49,5 \\
\hline Within the last three months & 27 & 14,2 \\
\hline Within the last six months & 10 & 5,3 \\
\hline Within the last year & 4 & 2,1 \\
\hline
\end{tabular}

When we evaluate the frequency of shopping by the participants related to the clothing (garment and shoes) product group, it could be seen that almost half of them shopped several times a month, and $25.8 \%$ thereof shopped once a month. When the findings are evaluated according to the time the last sopping was performed in relation to clothing (garment and shoes) product group, it is possible to say that almost $50 \%$ of the participants shopped in the last one month. The rate of those who shopped the last time for clothing (garment and shoes) product group in the last one week, to those who shopped the last time in the last three months was found to be around two folds.

\subsection{Products Mostly Purchased in Shopping}

In the study, for 28 products which are also included in the research carried out by Davis, Lang and Diego (2013) were categorized and adapted for the study.

In the study, the participants were asked to list the product categories they purchased the most in their shopping from 1 to 3 according to the level of significance (1: Most significant, 2: Less significant....) Findings obtained are given in Table 4. 
Table 4. Distribution of Mostly Purchased Products

\begin{tabular}{|l|c|c|}
\hline Product Categories & Frequency & Weight Score * \\
\hline Books, magazines and stationary & 94 & 211 \\
\hline Cinema, theater etc. activity tickets & 50 & 89 \\
\hline Cosmetic and personal care products & 69 & 132 \\
\hline Jewelry (necklace, ring, wristlet etc.) & 23 & 41 \\
\hline Gift and ornaments & 16 & 29 \\
\hline Accessories (bags, watches, eyeglasses etc.) & 26 & 57 \\
\hline $\begin{array}{l}\text { Technological products (computers, cameras, } \\
\text { mobile phones etc.) }\end{array}$ & 32 & 54 \\
\hline Houseware and utilities & & \\
\hline Sports items & 26 & 57 \\
\hline Film, music CD/ DVD & 9 & 14 \\
\hline Garments and shoes & 139 & 335 \\
\hline Banking services & 12 & 20 \\
\hline Travel (bus and airplane) tickets & 28 & 87 \\
\hline
\end{tabular}

*Weighted points were obtained by coding the order of preference for each product category in the reverse order and multiplying with their frequencies and arriving at the total value (For example, for gift and ornament items, $1^{\text {st }}$ preference is reverse coded with $3,2^{\text {nd }}$ with 2 and $3^{\text {rd }}$ with 1 , and their were multiplied with their frequencies and then added up. For gift and ornaments $=(3 * 3)+(7 * 2)+(6 * 1)=29$

Taking into account the weighted scores calculated according to the order of importance of product categories which are purchased the most , "garment and shoes" "book, magazine and stationary" and "cosmetic and personal care products" have the first three ranks amongst other product categories. Among the products which are purchased during shopping, film music CD/ DVD and "banking services" have the last two ranks.

\subsection{Elements That Affect Shopping Towards Clothing (Garment and Shoes) Product Groups}

In the study, the participants were asked by means of the following options the elements that had an impact on their shopping for clothing (garment and shoes) product group and the participants were stated that they could mark more than one options. Findings related to the responses given by the participants are given in Table 5. 


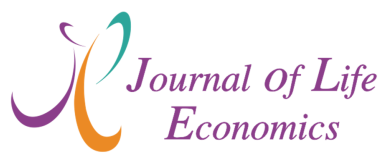

Table 5: Elements That Affect Shopping Towards Clothing (Garment and Shoes) Product Groups

\begin{tabular}{|l|c|c|c|}
\hline \multirow{2}{*}{ Elements That Affect Shopping } & \multicolumn{2}{|c|}{ Answers } & \% of \\
\cline { 2 - 4 } & f & \% & Responders \\
\hline I see that there is a discount on the product & 144 & 30,4 & 75,8 \\
\hline I decide at that moment that I need that product & 125 & 26,4 & 65,8 \\
\hline The effect of people with whom I am shopping & 54 & 11,4 & 28,4 \\
\hline My irresistible desire for purchasing the product & 24 & 5,1 & 12,6 \\
\hline I get excited when I see the product & 58 & 12,2 & 30,5 \\
\hline I do not want to lose the product & 48 & 10,1 & 25,3 \\
\hline The atmosphere of the shop where I do shopping & 19 & 4,0 & 10 \\
\hline Other & 2 & 0,4 & 1,1 \\
\hline Total & $\mathbf{4 7 4}$ & $\mathbf{1 0 0}$ & $\mathbf{2 4 9 , 5}$ \\
\hline
\end{tabular}

Since the participants were asked to mark three options, the frequencies are taken according to multiple response set and the total given is rated according to the response.

When the findings obtained are taken into account, $75.8 \%$ of the responders indicated that the leading among the elements that have impact on their shopping for clothing (garments and shoes) product groups was that they see a discount in the product. The second and third elements among those which have impact on shopping for clothing (garment and Shoes) product group were "deciding at that moment that the person needs that product" and "getting excited when the persons sees the product". For the participants, the elements of "atmosphere of the shop where I do shopping" and "having an irresistible desire to purchase the product" rank the last.

\subsection{Scales Used in the Research}

In this study, in order to determine which of the type A and type B personalities the participants have, Short Form of Bortner Rating Scale) (SFBRS) was used, which was also used previously by Aktaş (2001), Erdoğan and Zengin, (2012) and Yıldız and Özsoy (2013). The short form of the scale in question is a likert type (8 rates) scale and comprises 7 expressions with two opposite poles. The evaluation is made by multiplying the total score obtained at the end of the scale by 3 and if the score of the participant is more than 100 , he / she is decided to have type A personality, and if it is less than 100, he/ she is decided to have type B personality (the highest score is 168, and the lowest score is 21) (Aktas,2001). In this regard, young consumers in this research who have a total score for the scale of above 100 have been accepted as "type A personality" and young consumers who have a total score of below 100 have been accepted as "type B personality"

For measuring the voluntary simplicity lifestyle, the "Voluntary Simplicity Lifestyle" scale, which is developed by Özgül (2008) by using the studies of Shama (1985) and Iwata (2006) has been used. In the scale developed by Özgül (2008), who studied the subject at Turkey scale, it was asserted that the voluntary simplicity lifestyle comprises the dimensions of planned shopping, not putting emphasis on the non-material elements of life, selecting simple products and self- sufficiency. Özgül's (2008) classification has been adopted due to the fact that the voluntary simplicity comprises dimensions which express rather similar meanings in the scaled developed in relation to the subject, but that this differs depending on the structure and the cultural characteristics of the society, and that this study is conducted in Turkey and its closeness with the theoretical definitions of voluntary simplicity in terms of the dimensions considered. In this regard, the Likert scale of 5 (1: Strongly disagree..........5: 


\section{$\int\left(\begin{array}{c}\text { Journal of Life } \\ \text { Economics }\end{array}\right.$}

Strongly agree), which comprises a total of 8 questions and stipulates that the voluntary simplicity lifestyle includes planned shopping, importance put on material life, simplicity in the product and self-sufficiency, was taken as basis for the measurement.

\subsection{Exploratory Factor Analysis Towards Voluntary Simplicity Lifestyle}

Internal consistency factor (Cronbach Alpha) was calculated for items which constitute the scale of 8 statements and which are used for measuring attitudes towards voluntary simplicity lifestyle, was calculated and "fundamental components factor analysis" was applied.

The KMO (Kaiser-Meyer-Olkin) value which shows the appropriateness of the factor analysis ws found as 0,736. These values are above 0,70, which is the critical value (Malhotra,1996; ref:Altunışık et al.,2012:268) and demonstrate that the condition of adequacy of the sample is satisfied. Together with this, the "anti-image" factors were separately examined towards the classification of variables that have a distorting effect on the factor analysis, and there was no expression that needs to be removed. When the factor charges are taken into consideration, no expression was encountered which has a factor charge of less than 0.50 and which is not completely separated.

Table 6 shows the findings related to factor analysis. The findings explain 70,690\% of the total variance of four dimensions constituting the scale used for determining the attitudes related to voluntary simplicity lifestyle. Results of the reliability test (Cronbach Alpha) developed in relation to each factor are above 0,70 , which is the critical value, or well close to 0,70 (Özdamar,2004). 
Table 6: Results of Explanatory Factor Analysis Towards Voluntary Simplicity Lifestyle

\begin{tabular}{|c|c|c|c|c|}
\hline \multirow[b]{2}{*}{ Factors } & \multicolumn{4}{|c|}{ Factor Charges } \\
\hline & $\begin{array}{c}\text { Factor } \\
1\end{array}$ & $\begin{array}{c}\text { Factor } \\
2\end{array}$ & \begin{tabular}{|c|} 
Factor \\
3
\end{tabular} & $\begin{array}{c}\text { Factor } \\
4\end{array}$ \\
\hline \multicolumn{5}{|l|}{ Planned Shopping } \\
\hline $\begin{array}{l}\text { - Even if I have money, making unplanned shopping does not fit into } \\
\text { my principles } \\
\text { - While shopping, I look at whether a product is really necessary for } \\
\text { me, and I make my decision accordingly }\end{array}$ & $\begin{array}{l}, 863 \\
, 763\end{array}$ & & & \\
\hline \multicolumn{5}{|l|}{ Self-Sufficiency } \\
\hline $\begin{array}{l}\text { - I would like to have a life in which I am self-sufficient in the future } \\
\text { - The fact that a human being is self-sufficient in terms of income and } \\
\text { expenditure balance, is a desired thing }\end{array}$ & & $\begin{array}{l}, 867 \\
, 712\end{array}$ & & \\
\hline \multicolumn{5}{|l|}{ Simplicity in Product } \\
\hline $\begin{array}{l}\text { - I prefer simple products which satisfy my needs rather than complex } \\
\text { and multi-functional products } \\
\text { - Generally I do not purchase products which have developed } \\
\text { specifications and are hard to be used }\end{array}$ & & \multicolumn{3}{|c|}{,856 } \\
\hline \multicolumn{5}{|l|}{ Intangible Life } \\
\hline $\begin{array}{l}\text { - I am interested in my personal development rather than economic } \\
\text { development. } \\
\text { - I emphasize mental development and success more than material } \\
\text { richness }\end{array}$ & & & & $\begin{array}{l}, 922 \\
, 612\end{array}$ \\
\hline Variance Disclosed \% & $\frac{1}{20,274}$ & 18,135 & 17,308 & 14,972 \\
\hline Cronbach's Alpha & ,702 & 678 & ,632 & 621 \\
\hline $\begin{array}{l}\text { Kaiser-Meyer-Olker (KMO) Sample Sufficiency } \\
\text { Bartlett's Test of Sphericity }\end{array}$ & $\chi^{2}=181,205$ & \multicolumn{2}{|c|}{$\mathbf{d f}=28$} & $\begin{array}{l}, 736 \\
, 000\end{array}$ \\
\hline
\end{tabular}

\subsection{Comparison of Dimensions Related to Voluntary Simplicity Lifestyle In} Terms of Personality Type (A-B)

Results related to comparisons made with Independent samples t-Test in order to demonstrate whether dimensions related to voluntary simplicity lifestyle differentiate in terms of personality type (type A-B) are given in Table 7.

Table 7: Comparison of Dimensions Related to Voluntary Simplicity Lifestyle In Terms of Personality Type (A-B) - Independent Samples t-Test Results

\begin{tabular}{|l|c|c|c|c|c|}
\hline \multicolumn{1}{|c|}{ Dimensions } & $\begin{array}{c}\text { Personal } \\
\text { ity Type }\end{array}$ & N & Average & $\begin{array}{c}\text { Standard } \\
\text { Deviation }\end{array}$ & $\begin{array}{c}\text { Standard } \\
\text { Error of } \\
\text { Average }\end{array}$ \\
\hline \multirow{2}{*}{ Planned Shopping* } & $\mathrm{A}$ & 99 & 3,506 & 1,034 &, 108 \\
\cline { 2 - 6 } & $\mathrm{B}$ & 91 & 3,737 &, 959 &, 096 \\
\hline \multirow{2}{*}{ Self-Sufficiency } & $\mathrm{A}$ & 99 & 4,323 &, 774 &, 077 \\
\cline { 2 - 6 } & $\mathrm{B}$ & 91 & 4,308 &, 748 &, 078 \\
\hline \multirow{2}{*}{ Simplicity in Product** } & $\mathrm{A}$ & 99 & 3,187 &, 979 &, 103 \\
\cline { 2 - 6 } & $\mathrm{B}$ & 91 & 3,535 &, 818 &, 082 \\
\hline \multirow{2}{*}{ Intangible Life $* * *$} & $\mathrm{~A}$ & 99 & 3,538 &, 854 &, 089 \\
\cline { 2 - 6 } & $\mathrm{B}$ & 91 & 3,783 &, 786 &, 079 \\
\hline
\end{tabular}

$* t=-2,702 ; s d=188 ; p=, 006$

$* * t=-2,670 ; s d=188 ; p=, 008$

$* * * t=-2,054 ; s d=188 ; p=, 041$ 


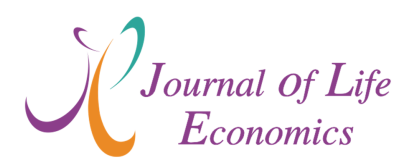

According to the results of Independent sample t-Test which compares the averages of responses given to planned shopping, self-sufficiency, simplicity in product and immaterial life voluntary simplicity lifestyles from the point of view of personality type, it could be seen that there is statistically significant difference in planned shopping, product simplicity and immaterial life dimensions $(\mathrm{p}<0.05)$. When the averages of responses given according to both planned behavior and product simplicity and immaterial life dimension, it could be stated that participants who have type B personality in all of three dimensions were more towards planned shopping, and looked for simplicity in product and adopted an immaterial life style, compared to participants having type A personality, from a statistical perspective.

\section{DISCUSSION AND CONCLUSION}

As a result of the explanatory factor analysis which is carried out towards voluntary simplicity lifestyle under the research, four factors comprising planned shopping, selfsufficiency, product simplicity and immaterial life have emerged. Four dimensions which have arisen by conducting explanatory factor analysis in this research, coincide with the findings of studies carried out by Özgül (2008). Besides the research findings explain 70,690 $\%$ of the total variance of four dimensions constituting the scale used for determining the attitudes related to voluntary simplicity lifestyle

Results of the study which is carried out in order to examine the voluntary simplicity lifestyles of consumers from the point of view of personality characteristics (type A-B), demonstrate that at dimensions which constitute voluntary simplicity lifestyle, in all of the sub-dimensions other than self-sufficiency dimension the averages of responses given have a statistically significant difference from the point of type A and B personality. Results of the study demonstrate that the averages of responses given in the three dimensions (planned behavior, simplicity in product and intangible life) show that participants having type B personality are directed more towards more planned shopping and also they looked from simplicity in the product and also they adopted an intangible life style, compared to participants having type A personality in statistical terms.

Results related to shopping frequencies and shopping times of participants as regards the clothing (garments and shoes) product groups demonstrate that almost half of the participants shop several times a month for the product group in question and also that around $50 \%$ of them shopped in the last one month. Taking into account the weighted scores calculated according to the order of importance of product categories which are purchased the most , "garment and shoes" "book, magazine and stationary" and "cosmetic and personal care products" have the first three ranks amongst other product categories. Together with this, taking into account the elements which affect shopping for clothing (garment and shoes) product groups, a striking result appears as three fourths of the responders indicated the first element as "seeing that there is a discount in the product" and the last element as "becoming excited after seeing the product".

In the literature search carried out on the research subject, no sufficient amount of study was encountered where voluntary simplicity lifestyle and personality types are analyzed together, which demonstrates that this could be an area of further contribution by the academicians and researchers in this aspect. Besides, important clues could be derived from the responses given to questions which were analyzed under the scope of the research in order for the enterprises in the clothing (garments and shoes) sector to understand the consumers and create marketing programs towards the consumers in question. 


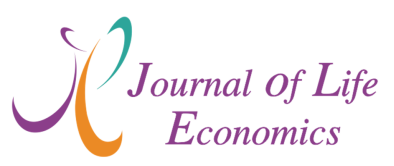

Taking into account the fact that studies in which type A and type B personality characters are associated with voluntary simplicity lifestyle have not been sufficiently conducted in the consumer behavior literature, this research appears to be important in terms of both filling this gap and demonstrating the difference of voluntary simplicity lifestyle from the point of view of personality characteristics (type A and B).

When the findings of the research are evaluated in general, it is considered that studies to be conducted in the future on voluntary simplicity lifestyle and personality characteristics should continue in a deeper manner. In the shopping preferences in case of studies in which both personal characteristics and voluntary simplicity lifestyle are handled together, both the researchers and the marketers could benefit from researches to be conducted taking into account such socio-economic variables as gender, income status, educational status in the product and/ or services purchased by the consumers.

Since in this research the sample comprises the consumers that are selected by easy sampling method from among consumers aged 18 and above who shop clothing (garments and shoes) from a shopping mall in Sakarya province, this is characterized as a restriction in terms of generalization of the results. For that reason, it is considered that it would be more beneficial to use sampling methods based in particular on probability in case of studies to be conducted in the future and to carry out the research from the point of different product and product specifications from samples having different characteristics.

In this research a qualitative research design is adopted and the survey is used as data collection method. Although focus groups are realized for determining the elements that have impact on shopping for clothing (garments and shoes) product groups, in the researches to be conducted in the future, it could be beneficial to reveal elements in question by carrying out in depth interview and focus group works in different samples. Together with this, performing mixed studies where both qualitative and quantitative works are jointly used by including quantitative research patterns in order to handle the issue in a more comprehensive manner, will be beneficial both to academicians and researchers working in this field, as well as the implementers.

When considered from the point of view of implementers and enterprises in the marketing field, knowing the shopping styles and personality types of consumers is particularly important in performing market segmentation and market positioning of the products. In addition to this, knowing which product groups are preferred by the consumers who adopt voluntary simplicity lifestyle in their shopping and revealing the elements that have impact on shopping and knowing which are more preferred could contribute in determining the promotion activities towards products and/or services to be presented to consumers and increase their impact. 


\section{$\int$ Journal of Life \\ REFERENCES}

Aktaş, A. M., 2001, Bir Kamu Kuruluşunun Üst Düzey Yöneticilerinin İş Stresi ve Kişilik Özellikleri, Ankara Üniversitesi Siyasal Bilgiler Fakültesi Dergisi,(8.56):26-42.

Altunışık, R., Ş. Özdemir ve Ö. Torlak, 2006, Modern Pazarlama, Değişim Yayınları, 4. Basım, İstanbul.

Argan, M., Argan, M. T. ve N. Sevim, 2012, Tükenmeden Tükettiren Yaşam Tarzı: Gönüllü Sadelik", 17. Ulusal Pazarlama Kongresi Bildiri Kitabı, Balıkesir Üniversitesi Yayın No 39, Burhaniye Uygulamalı Bilimler Yüksekokulu, Yayın No:1, ss. 201-220

Aslay, F., Ünal, S. ve Ö. Akbulut, 2013, Materyalizmin Statï Tüketimi Üzerindeki Etkisini Belirlemeye Yönelik Bir Araştırma, Ataturk University Journal of Economics \& Administrative Sciences, C. 27, No: 2.

Aytaç, T., 2002, Eğitim ve Yönetimde Yeni Yaklaşımlar Zaman Yönetimi, Bilim ve Aklın Aydınlı̆̆ında Eğitim Dergisi, Temmuz, http://yayim.meb.gov.tr/yayimlar/sayi29/aytac.htm, 24. 05. 2003.

Babaoğul, M. ve E.B. Buğday, 2012, Gösteriş Tüketimine Karşı Gönüllü Sadelik, Tüketici Yazıları III. Derleyen: Babaoğul, M., Şener, A., Buğday, E. B., Elma Teknik Basım, Ankara.

Balkıs, M., 2006, Üniversite Öğrencilerinin Düşünme Stilleri İle Kişilik Tipleri Arasındaki İlişkinin Çeşitli Değişkenler Açısından İncelenmesi. Yayınlanmamış Yüksek Lisans Tezi, Dokuz Eylül Üniversitesi Sosyal Bilimler Enstitüsü, İzmir.

Ballantine, P. W. ve Creery, S., 2010, The Consumption and Disposition Behaviour of Voluntary Simplifiers, Journal of Consumer Behaviour, C. 9, No: 1, ss. 45-56.

Bekin, C., Carrigan, M. ve Szmigin, I., 2005, Defying Marketing Sovereignty: Voluntary Simplicity at New Consumption Communities, Qualitative Market Research: An International Journal, C. 8, No: 4, ss. 413-429.

Brown, K. W. ve Kasser, T., 2005, Are Psychological and Ecological Well-Being Compatible? The Role of Values, Mindfulness, and Lifestyle, Social Indicators Research, C. 74, No: 2, ss. 349-368.

Cengiz, H., 2014, Gönüllü Sade Yaşam Davranışının Ölüm Tüketimi Davranışına Yönelik Tutumlar Üzerine Etkisi: Türk Ve Amerikan Kültürleri Arasında Bir Karşılaştırma, Yayınlanmamış Yüksek Lisans Tezi. Eskişehir: Eskişehir Osmangazi Üniversitesi SBE.

Cowles, D. ve Crosby, L. A., 1986, Measure Validation in Consumer Research: A Confirmatory Factor Analysis of The Voluntary Simplicity Lifestyle Scale, Advances in Consumer Research, C. 13, No: 1, ss. 392-397.

Craig-Lees, M. ve Hill, C., 2002, Understanding Voluntary Simplifiers, Psychology \& Marketing, C. 19, No: 2, ss. 187-210.

Cüceloğlu, D., 2003, İnsan ve Davranışı, Remzi Kitabevi. 12. Basım. İstanbul.

Davis, R., Lang, B. ve J.S. Diego, 2013, How Gender Affects The Relationship Between Hedonic Shopping Motivation And Purchase Intentions?, Journal of Consumer Behaviour, Vol. 13, no. 1, pp. 18-30. 


\section{$\int\left(\begin{array}{c}\text { Journal of Life } \\ \text { Economics }\end{array}\right.$}

Demirel, H., 2013, The Influence Of Personality Traits And Psychological Characteristics Of Individuals On Their Clothing Purchase Behaviors, Tekstil ve Konfeksiyon, 23(1), 67-76.

Doherty, D. ve Etzioni A., 2003, Voluntary Simplicity: Responding to Consumer Culture, Rowman and Littlefield, Oxford.

Dominguez, J. R. ve Robin, V., 1992, Your Money or Your Life, Penguin Books.

Durna, U., 2005, A Tipi Ve B Tipi Kişilik Yapıları Ve Bu Kişilik Yapılarını Etkileyen Faktörlerle İlgili Bir Araştırma, Íktisadi ve İdari Bilimler Dergisi, Cilt: 19 Nisan 2005 Say1: 1.

Edwars, J, R., A. S. JR. Baglioni ve C. L. Cooper, 1990, The Psychometric Properties of The Bortner Type A Scale. British Journal of Psychology. 81.3,15-33.

Elgin, D., 1981, Voluntary Simplicity: Toward A Way of Life That is Outwardly Simple, Inwardly Rich, William Morrow and Company, New York.

Elgin, D., 1993, Voluntary Simplicity: Toward a Way of Life that is Outwardly Simple, Inwardly Rich, New York, William Morrow and Company Inc.

Elgin, D., 2010, Voluntary Simplicity Second: Toward a Way of Life That Is Outwardly Simple, Inwardly Rich, HarperCollins.

Elgin, D. ve Mitchell, A., 1977, Voluntary Simplicity. The Co-Evolution Quarterly, 3 (Summer), 5-18.

Ensley, E. E., 1983, Voluntary Simplicity: A Segment Of Concern To Marketers?, Proceedings of the American Marketing Association, ss. 385-389.

Erdoğan, İ., 1994, İşletmelerde Davranış, Beta Basım Yayım Dağıtım, 4. Baskı. İstanbul.

Erdoğan. Ç. ve Zengin, B., 2012, Turizm Lisans Öğrencilerinin A ve B Tipi Kișilik Özelliklerine Göre Mesleki Yönelimlerinin Belirlenmesi: Sakarya Üniversitesi Örneği, XI. Geleneksel Turizm Paneli, 16 Nisan, Sakarya.

Eren, E., 2000, Örgütsel Davranış ve Yönetim Psikolojisi. Beta Basım Yayım Dağıtım, Genişletilmiş 6. Baskı. İstanbul.

Etzioni, A., 1998, Voluntary Simplicity, Characterization, Select Psychological Implications, and Societal, Consequences, Journal of Economic Psychology, C. 19, No: 5, ss. 619643.

Friedman H. H. ve Friedman L. W., 2010, Dying of Consumption? Voluntary Simplicity as an Antidote to Hypermaterialism, Derleyen: William Sun, Jim Stewart, David Pollard (ed.), Reframing Corporate Social Responsibility: Lessons from the Global Financial Crisis (Critical Studies on Corporate Responsibility, Governance and Sustainability, C. 1, Emerald Group Publishing Limited, ss. 253-269.

Friedman, M., ve R. H. Rosenman, 1959, Association of Specific Overt Behavior Pattern with Blood and Cardiovascular Findings. Journal of the American Medical Association,169, 1286-1296.

Gregg R., 1936, The Value of Voluntary Simplicity, Pendle Hill: Wallingford, PA. 


\section{$\int \begin{gathered}\text { Journal of Life } \\ \text { Economics }\end{gathered}$}

Huneke, M. E., 2005, The Face of The Un-Consumer: An Empirical Examination of The Practice of Voluntary Simplicity in The United States, Psychology \& Marketing, C. 22, No: 7, ss. 527-550.

Iwata, O., 1997, Attitudinal and Behavioral Correlates of Voluntary Simplicity Lifestyles, Social Behavior and Personality, 25: 233-240.

Iwata, O., 2006, An Evaluation of Consumerism and Lifestyle as Correlates of a Voluntary Simplicity Lifestyle", Social Behavior and Personality, 34(5): 557-568.

İslamoğlu, A. H. ve Altunışık, R., 2008, Tüketici Davranışları, İstanbul: Beta Yayıncılık.

Johnson, B., 2004, Simply Identity Work? The Voluntary Simplicity Movement, Qualitative Sociology, 27(4), 527-530.

Kutlu, E., 2016, Tüketici Kişiliği Ve Marka Kişiliği İlişkisi: Sosyal Medya Tercihleri Üzerine Bir Araştırma, Yayınlanmamış Yüksek Lisana Tezi. Sakarya: Sakarya Üniversitesi SBE.

Lelord. F. ve C. Andre, 1996, Zor Kişilikler'le Yaşamak (Çev. R Madenci), İstanbul: İletişim Yayınları.

Leonard-Barton, D., 1981, Voluntary Simplicity Lifestyles and Energy Conservation, Journal of Consumer Research, C. 8, No: 3, ss. 243-252.

Leonard-Barton, D. ve E. M. Rogers, 1979, Adoption of Energy Conservation among California Homeowners, International Communication Association Meeting.

Luthans, F., 1995, Organizational Behavior, 7. B., Literatür Yay., İstanbul.

Maslow, A., 1954, Motivation and Personality, Harper, New York.

Morgan, C. T., 2009, Psikolojiye Giriş. S. Karakaşve R. Eski (Çev.). Konya: Eğitim Kitapevi.

Myer, D., 2003,Wealth and Happiness: A Limited Relationship, Doherty et al.(eds.) Voluntary Simplicity: Responding the Consumer Culture, Maryland, Rowman and Littlefeld Puplisers Inc.

Nolen, T. P. ve Clawson, B., 1995, Choosing Voluntary Simplicity as a Lifestyle, Journal of Family and Consumer Sciences Education, C. 13, No: 2.

Odabaşı, Y., 2006, Tüketim Kültürü - Yetinen Toplumun Tüketen Topluma Dönüşümü, İstanbul, Sistem Yayıncılık.

Odabaşı, Y. ve Barış, G., 2006, Tüketici Davranışı. MediaCat Yayınları. 6. Basım. İstanbul.

Özdamar, K., 2004, Paket Programlarla İstatistiksel Veri Analizi, Eskişehir: Kaan Kitabevi.

Özgül, E., 2008, Tüketicilerin Değer Yönelimleri, Gönüllü Basit Yaşam Tarzı ve Sürdürülebilir Tüketim Üzerindeki Etkileri, 13.Ulusal Pazarlama Kongresi Bildiri Kitabl, Adana.

Özgül, E., 2009, Tüketicilerin Gönüllü Sade Yaşam Tarzı ve Sürdürülebilir Tüketim Davranışlarının Sosyo-Demografik Analizi, Finans Politik ve Ekonomik Yorumlar Dergisi, C. 46, No: 535, ss. 13-24.

Özgül, E., 2011, Tüketicilerin Sosyo-Demografik Özelliklerinin Hedonik Tüketim ve Gönüllü Sade Yaşam Tarzları Açısından Değerlendirilmesi, Ege Academic Review, C. 11, No: 1, ss. 25-38. 


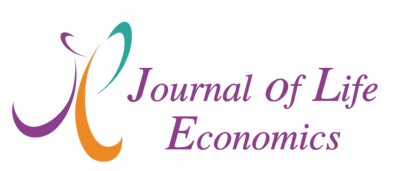

Pierce, L.B., 2000, Choosing Simplicity: Real People Finding Peace and Fulfillment in A Complex World, Gallagher Press.

Schor, J. B., 1998, The Overspent American: Upscaling, Downshifting and The New Consumer, Basic Books, New York.

Semiz, B. B., 2015, Tüketicilerin Kişilik Tiplerinin Satın Alma Tarzlarına Etkisinin İncelenmesi", 20. Ulusal Pazarlama Kongresi, 10-13 Haziran, Eskişehir.

Shama, A.(1981). Coping with Staglation: Voluntary Simplicity, The Journal of Marketing, C. 45, No: 3, ss. 120-134.

Shama, A., 1985, The Voluntary Simplicity Consumer, The Journal of Consumer Marketing, 2: 57-63.

Shama, A., 1988, The Voluntary Simplicity Consumer: A Comparative Study, Psychological Reports, C. 63, No: 3, ss. 859-869.

Somer, O., Korkmaz, M. ve A. Tatar, 2004, Kuramdan Uygulamaya Beş Faktör Kişilik Modeli ve Beş Faktör Kişilik Envanteri (5FKE), Ege Üniversitesi Edebiyat Fakültesi Yayınları, No:128, İzmir.

Tutar, H., 2015, Mobbing (Nedenleri ve Başa Çıkma Stratejileri: Kuramsal Yaklaşım), Detay Yayıncılık, Şubat 2015 1.Baskı, 180-189.

Walther, C. S. ve Sandlin, J. A., 2013, Green Capital and Social Reproduction Within Families Practising Voluntary Simplicity in The US, International Journal of Consumer Studies, C. 37, No: 1, ss. 36-45.

Yıldız, G. ve E. Özsoy, 2013, Çalışanların Kişilik Özelliğine Göre İş Doyumu Farklılaşır Mı? Sosyal ve Beşeri Bilimler Dergisi (Online), Cilt 5, No 1, ss.268-278.

Yurtsever, H., 2009, Kişilik Özelliklerinin Stres Düzeyine Etkisi Ve Stresle Başa Çıkma Yolları:Üniversite Öğrencileri Üzerine Bir Araştırma, Yayınlanmamış Yüksek lisans Tezi, İzmir: Dokuz Eylül Üniversitesi, S.B.E.

Zavestoski, S., 2002, The Social-Psychological Bases of Anticonsumption Attitudes, Psychology \& Marketing, C. 19, No: 2, ss. 149-16.

Zel, U., 2011, Kişilik ve Liderlik. Nobel Yayınları, 3. Basım. Ankara. 
$\int\left(\begin{array}{c}\text { Journal of Life } \\ \text { Economics }\end{array}\right.$ 